\title{
Functionalization of naphthalene: a novel synthetic route to brominated naphthoquinones
}

\author{
Osman Cakmak, ${ }^{a} *$ Kiymet Berkil Akar, ${ }^{b}$ and Nuri Kaplan ${ }^{a}$ \\ ${ }^{a}$ Department of Chemistry, Faculty of Art and Science, Gaziosmanpasa University, \\ 60250 Tokat, Turkey \\ ${ }^{b}$ Department of Bioengineering, Faculty of Engineering and Natural Science, \\ Gaziosmanpasa University, 60250 Tokat, Turkey \\ E-mail: cakmak.osman@gmail.com
}

\section{Dedicated to Professor Keith Smith on the occasion of his 65th anniversary}

\begin{abstract}
An efficient procedure is described for synthesis of 2,5,8-tribromonaphthoquinone (12) from naphthalene in four reaction steps. Silver-promoted solvolysis of hexabromide $\mathbf{3}$ produces the specific diastereostereoisomer 10. Dehydrobromination of $\mathbf{1 0}$ using sodium methoxide gives tribromodihydronaphthalene-1,4-diol 11 in high yield. PCC oxidation of either 10 or 11 results in the formation of 2,5,8-tribromonaphthalene-1,4-dione (12).
\end{abstract}

Keywords: Bromonaphthalene, bromination, silver-induced substitution, 1,4-naphthoquinone, PCC oxidation

\section{Introduction}

The naphthoquinone structure exists in many natural products and biologically active compounds. ${ }^{1}$ Among the naphthaquinones, 2-substituted-1,4-naphthoquinone derivatives are especially interesting molecules because of the their extremely important biological activities, such as antibacterial, ${ }^{2}$ antitrypanosomal, ${ }^{3}$ antileishmanial, ${ }^{3}$ molluscicidal, ${ }^{4}$ cytotoxic ${ }^{5}$ and antitumor ${ }^{6}$ properties.

Naphthoquinones are industrially used as raw materials for pharmaceuticals, agrochemicals and other chemicals. ${ }^{7}$ Therefore, development of novel synthetic methodologies for the synthesis of naphthoquinones is an important task for chemists. ${ }^{8}$

Our studies have shown that bromination conditions dramatically affect the regio- and stereoselectivity of bromination reactions. ${ }^{9}$ Different products are obtained depending on both the structures of the starting materials and the reaction conditions. For example, while 
photobromination of naphthalene leads to trans,trans,trans-tetrabromide $4,{ }^{9 a}$ photobromination of 1,4-dibromonaphthalene $\mathbf{2}$ affords compound $\mathbf{3}^{10}$ On the other hand, bromination of naphthalene $\mathbf{1}$ at $-30{ }^{\circ} \mathrm{C}$ produces compound 2. ${ }^{9 \mathrm{~b}}$

We have developed a new strategy for the preparation of 1,4-dihydroxytetralins (and similarly their anthracene counterparts) by silver-induced hydrolysis of 1,2,3,4-tetrabromotetralins, which are good precursors for the synthesis of naphthalene (or anthracene) epoxides. ${ }^{9-f}$ These studies showed that such 1,4-dihydroxy compounds are useful intermediates for polyfunctionalisation of aromatic compounds (Scheme 1). Thus, base-induced dehydrobromination of $\mathbf{6}$ produces the epoxide 7. By contrast, similar treatment of $\mathbf{8}$, obtained from the hexabromide 5, gives the aromatized product 9. Recently, in the case of a 1,4-dihydoxy-3,4dibromoanthracene, we showed that dehydrobromination led to a product that was neither aromatized nor contained an epoxide unit. ${ }^{9 g}$

In this paper we describe the application of silver-induced hydrolysis to compound $\mathbf{3}$, which led to a synthesis of 2,5,8-tribromonaphthoquinone (12) in four steps starting from naphthalene.<smiles>BrC1c2ccccc2[C@@H](Br)C(Br)[C@@H]1Br</smiles><smiles>C[C](Cl)Br</smiles><smiles>c1ccc2ccccc2c1</smiles>

$\mathrm{Br}_{2}$ $\mathrm{CH}_{2} \mathrm{Cl}_{2},-30{ }^{\circ} \mathrm{C}$

$\checkmark$ dark<smiles>Brc1ccc(Br)c2c1C(Br)C(Br)C(Br)C2Br</smiles>

3

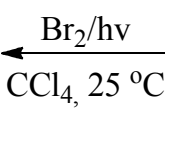

$$
\frac{\mathrm{CH}_{3} \mathrm{ONa}}{\mathrm{THF}, 25^{\circ} \mathrm{C}}
$$

7<smiles>Brc1ccc(Br)c2ccccc12</smiles>

2

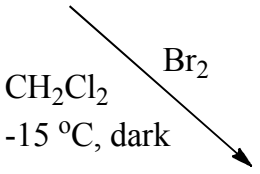<smiles>OC1c2c(Br)ccc(Br)c2[C@H](O)[C@@H](Br)[C@@H]1Br</smiles>

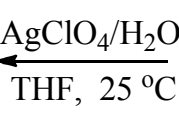<smiles>COc1cc(Br)cc2c(Br)ccc(Br)c12</smiles><smiles>COC1c2c(Br)ccc(Br)c2C(OC)C(Br)C1Br</smiles>

8 $\uparrow \begin{aligned} & \mathrm{Ag}_{2} \mathrm{SO}_{4} \\ & \mathrm{MeOH}, 25{ }^{\circ} \mathrm{C}\end{aligned}$<smiles>Brc1ccc(Br)c2c1C(Br)C(Br)C(Br)C2Br</smiles>

Scheme 1. Transformations of bromonaphthalenes. 


\section{Results and Discussion}

Our previously reported simple synthetic method was used for the preparation of 1,4-dibromonaphthalene $\mathbf{2}$, and the stereoselective synthesis of hexabromide $\mathbf{3}$ was efficiently achieved by its photobromination, according to the literature method. ${ }^{10}$

Hexabromide 3 was subjected to silver ion-assisted hydrolysis in aqueous acetone. The substitution resulted in the stereoselective formation of product $\mathbf{1 0}$ in $87 \%$ yield (Scheme 2). On the basis of NMR data, the compound contains two hydroxy groups. The reaction can afford two stereoisomers, one of which is symmetrical. The ${ }^{13} \mathrm{C}$ NMR spectrum confirms the unsymmetrical structure, consisting of ten carbon signals: two $\mathrm{CH}$ and four quaternary aromatic carbons, two $\mathrm{sp}^{3}$ carbons bearing hydroxyl groups and two $\mathrm{sp}^{3}$ carbons bearing bromine atoms.

In the ${ }^{1} \mathrm{H}$ NMR spectrum, the aromatic $\mathrm{H}-6$ and $\mathrm{H}-7$ protons resonate at $\delta 7.58$ and $\delta 7.53$ as an AB system $\left(J_{6-7} 8.5 \mathrm{~Hz}\right.$,). Benzylic proton $\mathrm{H}-4$ shows as a doublet of doublets at $\delta 5.07\left(J_{4-\mathrm{OH}}\right.$ $\left.8 \mathrm{~Hz} ; J_{4-3} 5 \mathrm{~Hz}\right)$, while the resonance of the hydroxy proton $(\mathrm{C}-4-\mathrm{OH})$ is a doublet at $\delta 3.01(\mathrm{C}$ $\left.4-\mathrm{OH}, J_{4-\mathrm{OH}} 8 \mathrm{~Hz}\right)$. The $\mathrm{H}-1$ proton resonance shows as a doublet of doublets at $\delta 5.51\left(J_{1-\mathrm{OH}} 4\right.$ $\left.\mathrm{Hz}, J_{1-2} 2.8 \mathrm{~Hz}\right)$. The hydroxyl resonance $(\mathrm{C}-1-\mathrm{OH})$ appears as a doublet at $\delta 2.90\left(J_{1-\mathrm{OH}} 4 \mathrm{~Hz}\right)$, and the H-2 and H-3 protons resonate at $\delta 4.72(b s)$ and $5.12\left(\mathrm{dd}, J_{3-4} 5 \mathrm{~Hz}, J_{2-3} 2.8 \mathrm{~Hz}\right)$.

After efficient and selective synthesis of dihydroxy compound 10, it was treated with one or two equivalents of sodium methoxide or pyridine. Surprisingly the reaction resulted in the formation of 11, instead of aromatisation product 13 and/or formation of epoxide $\mathbf{1 5}$. The favoured conformation of structure $\mathbf{1 0}$ will have one of the $\mathrm{sp}^{3}$ bromines pseudo axial and the other three groups on the saturated ring will be pseudo-equatorial. Antiperiplanar elimination of $\mathrm{H}$ and $\mathrm{Br}$ will remove the axial $\mathrm{Br}$ and an axial $\mathrm{H}$ and it clearly favours the more acidic hydrogen next to the other $\mathrm{Br}$, leading to $\mathbf{1 1}$. Formation of the epoxide would require the alternative conformation with three of the groups pseudo axial and although one of the $\mathrm{HBr}$ eliminations is not so difficult in going to $\mathbf{1 3}$, the other would also require the diaxial arrangement, which is unfavourable. Therefore the formation of the alkene $\mathbf{1 1}$ occurrs via an E1cB mechanism, as we discussed for transformation of its anthracene counterpart to alkene-1,4-diol. ${ }^{9 \mathrm{~g}}$

The mass spectrum of compound 11 gave a molecular ion peak $\mathbf{M}^{+}$at $m / z$ 396/398/400/402 corresponding to the formula $\mathrm{C}_{10} \mathrm{H}_{7} \mathrm{Br}_{3} \mathrm{O}_{2}$. The ${ }^{1} \mathrm{H}$ NMR spectrum of 11 showed an apparent singlet at $\delta 7.51$ due to aryl protons $\mathrm{H}-6$ and $\mathrm{H}-7$, a doublet $\left(J_{3-4} 3.6 \mathrm{~Hz}\right)$ at $\delta 6.62$ due to H-3 and a multiplet at $\delta$ 5.41-5.45 due to aliphatic protons $\mathrm{H}-1$ and $\mathrm{H}-4$. The hydroxyl protons appear as doublets at $\delta 3.17\left(\mathrm{~d}, J_{1-\mathrm{OH}} 5.6 \mathrm{~Hz}\right)$ and $\delta 3.08\left(\mathrm{~d}, J_{4-\mathrm{OH}} 6.0 \mathrm{~Hz}\right)$. The ${ }^{13} \mathrm{C} \mathrm{NMR}$ spectrum confirmed the structure, having ten signals.

It is clear that 1,4-dihydroxy compounds are good precursors for 1,4-diketones. Therefore, diol 11 was treated with pyridinium chlorochromate (PCC) in dichloromethane. After the oxidation, 2,5,8-tribromo-1,4-naphthoquinone 12 was isolated as the sole product (yield: 81$78 \%$, Scheme 2). The ${ }^{1} \mathrm{H}$ NMR spectrum of the compound consists of two signals, for H-6 and $\mathrm{H}-7(\delta 7.83$, bs $)$ and $\mathrm{H}-3(\delta 7.51, \mathrm{~s})$. The ${ }^{13} \mathrm{C}$ NMR spectrum showed the absence of aliphatic 
carbons. Two carbonyl signals at $\delta 179.8$ and $\delta 176.0$ were also consistent with the suggested structure. The IR spectrum showed two carbonyl bands at 1670 and $1608 \mathrm{~cm}^{-1}$.<smiles>c1ccc2ccccc2c1</smiles>

1

$$
\underset{\mathrm{CH}_{2} \mathrm{Cl}_{2},-30^{\circ} \mathrm{C}}{\stackrel{\mathrm{Br}_{2}(2 \mathrm{eq})}{\longrightarrow}}
$$$$
\mathrm{CH}_{2} \mathrm{Cl}_{2},-30 \mathrm{C}
$$<smiles>Brc1ccc(Br)c2ccccc12</smiles>

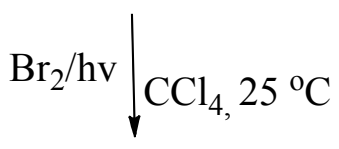<smiles>Brc1ccc(Br)c2c1[C@H](Br)[C@H](Br)[C@H](Br)[C@H]2Br</smiles>

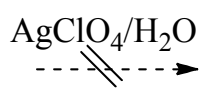

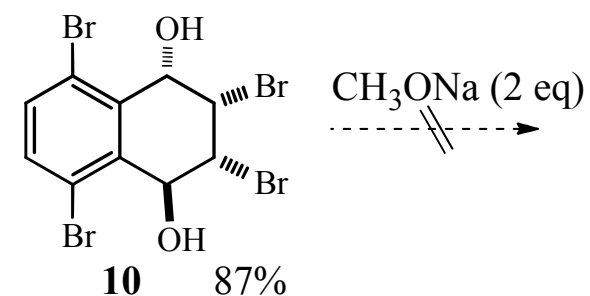
$\mathrm{CH}_{3} \mathrm{ONa}$ «...tf-... 15 $\mathrm{CH}_{3} \mathrm{ONa}$ Pyridine $25^{\circ} \mathrm{C}$

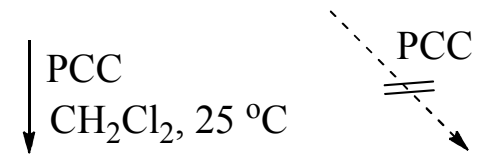<smiles>Oc1ccc(O)c2c(Br)ccc(Br)c12</smiles>

13<smiles>O[C@H]1c2c(Br)ccc(Br)c2[C@@H](O)[C@H](Br)[C@@H]1Br</smiles>
16<smiles>O[C@H]1C=C(Br)[C@H](O)c2c(Br)ccc(Br)c21</smiles>

$70 \%\left(\mathrm{CH}_{3} \mathrm{ONa}\right)$<smiles>O=C1C=C(Br)C(=O)c2c(Br)ccc(Br)c21</smiles>
12<smiles>O=C1c2c(Br)ccc(Br)c2C(=O)[C@@H](Br)[C@H]1Br</smiles>

14

$81 \%$ (pyridine)

$81 \%$ (from 11)

$86 \%$ (from 10)

Scheme 2. Synthesis of 2,5,8-tribromo-1,4-naphthoquinone 12. 
Interestingly, when the diol $\mathbf{1 0}$ was subjected to PCC, diketone $\mathbf{1 2}$ was again obtained, in $86 \%$ yield, instead of the expected diketone 14. Presumably, the pyridine moiety in the PCC acts as a base and the base removes either $\mathrm{H}-2$ or $\mathrm{H}-3$ in $\mathbf{1 0}$ to bring about elimination of one molecule of $\mathrm{HBr}$. Subsequently, oxidation would have occurred to form 12 (Scheme 2). Pyridine-induced elimination also afforded compound 11, which may support our assumption.

\section{Conclusions}

At the beginning of this study, we hoped to develop a convenient synthetic methodology for syndiepoxide 17, starting with hexabromide 3 and proceeding via diol $\mathbf{1 6}$ as shown in Scheme 2. However, the silver-induced hydrolysis afforded a stereoisomer, 10, that was different from the one expected. Moreover base-promoted reaction of $\mathbf{1 0}$ resulted in the alkene $\mathbf{1 1}$ instead of expected epoxide 15. These results directed our attention to a different possibility. Compound 11 was converted into 2,5,8-tribromo-1,4-naphthoquinone (12) by PCC oxidation. PCC oxidation of compound 10 also resulted in the formation of compound 12, not the anticipated compound 14. Thus, we have developed an effective and simple method for the synthesis of 2,5,8-tribromo-1,4naphthoquinone (12) starting from naphthalene and using just four/five sequential, precisely selective and simple reactions that all proceed in high yields. We believe that $\mathbf{1 2}$ can provide a practical lead to many natural and bioactive products due to the presence of its three bromine substituents.

\section{Experimental Section}

General. Thin layer chromatography was carried out on Merck $0.255 \mathrm{~mm}$ silica gel $\mathrm{F}_{254}$ analytical aluminium plates and spots were visualized with UV fluorescence at $254 \mathrm{~nm}$. Column chromatography was performed using silica gel 60 (70-230 mesh, Merck). Melting points were determined on a Thomas-Hoover capillary melting point apparatus. Infrared spectra were obtained from $\mathrm{KBr}$ pellet on a Jasco FT/IR 430 instrument. Elemental analyses were carried out on a LECO CHNS-93 analyser. Mass spectra were recorded on an Agilent 6890 GC System 5973 MSD spectrometer. NMR spectra were recorded on a Bruker Avance II spectrometer at 400 $\mathrm{MHz}$ for ${ }^{1} \mathrm{H}$ and $100 \mathrm{MHz}$ for ${ }^{13} \mathrm{C}$ NMR.

Hydrolysis of hexabromide 3; synthesis of diol 10. To a stirred solution of hexabromide 3 (4.0 $\mathrm{g}, 1.8 \mathrm{mmol})$ in acetone $(40 \mathrm{~mL})$ was added a solution of $\mathrm{AgClO}_{4} \cdot \mathrm{H}_{2} \mathrm{O}(1.22 \mathrm{~g}, 5.4 \mathrm{mmol})$ in aqueous acetone $(40 \%)$ in a dropwise manner in the dark. The resulting mixture was stirred at room temperature for 7 days in the dark, during which the reaction was monitored by TLC. The precipitated $\mathrm{AgBr}$ was filtered off and the filtrate was diluted with dichloromethane $(20 \mathrm{~mL})$. The organic layer was washed with $\mathrm{H}_{2} \mathrm{O}(3 \times 20 \mathrm{~mL})$ and dried over $\mathrm{Na}_{2} \mathrm{SO}_{4}$, and the solvent 
was removed under reduced pressure. The crude product $(2.92 \mathrm{~g})$ was recrystallized from dichloromethane to give pure $\mathbf{1 0}(2.77 \mathrm{~g}, 87 \%)$.

cis,cis,trans-2,3,5,8-Tetrabromo-1,2,3,4-tetrahydronaphthalene-1,4-diol (10). Mp 175-177 ${ }^{\circ} \mathrm{C} . \mathrm{R}_{f}: 0.42$ (hexane/ethyl acetate; 9:1); ${ }^{1} \mathrm{H} \mathrm{NMR}\left(400 \mathrm{MHz}, \mathrm{CDCl}_{3}\right) \delta 7.58\left(\mathrm{~d}, J_{6-7} 8.5 \mathrm{~Hz}, 1 \mathrm{H}\right.$, ArH), $7.53\left(\mathrm{~d}, J_{6-7} 8.5 \mathrm{~Hz}, 1 \mathrm{H}, \mathrm{ArH}\right), 5.51\left(\mathrm{dd}, J_{1-\mathrm{OH}} 4 \mathrm{~Hz}, J_{1-2} 2.8 \mathrm{~Hz}, 1 \mathrm{H}, \mathrm{H}-1\right), 5.12$ (dd, $J_{3-4}$ $5 \mathrm{~Hz}, J_{2-3} 2.8 \mathrm{~Hz}, 1 \mathrm{H}, \mathrm{H}-3$ ), 5.07 (dd, $\left.J_{3-4} 5 \mathrm{~Hz}, J_{4-\mathrm{OH}} 8 \mathrm{~Hz}, 1 \mathrm{H}, \mathrm{H}-4\right), 4.72$ (bs, 1H, H-2), 3.01 $\left(\mathrm{d}, J_{4-\mathrm{OH}} 8 \mathrm{~Hz}, 1 \mathrm{H}, \mathrm{OH}\right), 2.90\left(\mathrm{~d}, J_{1-\mathrm{OH}} 4 \mathrm{~Hz}, 1 \mathrm{H}, \mathrm{OH}\right) ;{ }^{13} \mathrm{C} \mathrm{NMR}\left(100 \mathrm{MHz}, \mathrm{CDCl}_{3}\right) \delta 136.6$, 135.3, 134.7, 134.4, 126.1, 124.8, 73.4, 68.9, 53.0, 48.5; MS (GC-MS/EI) m/z 378/380/382/384 $\left[2, \mathrm{M}^{-} \mathrm{H}_{2} \mathrm{O}-\mathrm{Br}\right]^{+}, 362 / 364 / 366 / 368\left[3, \mathrm{M}-2 \mathrm{H}_{2} \mathrm{O}-\mathrm{Br}-2 \mathrm{H}\right]^{+}, 317 / 319 / 321[9, \mathrm{M}-2 \mathrm{Br}-3 \mathrm{H}]^{+}, 301[1$, $\left.\mathrm{M}-\mathrm{H}_{2} \mathrm{O}-2 \mathrm{Br}\right]^{+}, 281\left[15, \mathrm{M}-2 \mathrm{H}_{2} \mathrm{O}-2 \mathrm{Br}-3 \mathrm{H}\right]^{+}, 250,252$ (100), 235 [51, M-3Br-4H] $]^{+}, 219$ (62), 207 (71), 193 (29), 147 [15, M-OH-4Br] ${ }^{+}, 131$ (43), 102 (32), 86 (22), 75 (46), 69 (73), 50 (22), 44 (100); IR (KBr, cm $\left.{ }^{-1}\right) 3303,2873,2358,1671,1432,1340,1311,1282,1182,1145,1064,1012$, $910,863,806,765,736,676,657,615,568,511,491,430$. Anal. calcd for $\mathrm{C}_{10} \mathrm{H}_{8} \mathrm{Br}_{4} \mathrm{O}_{2}: \mathrm{C}$, $25.03 ; \mathrm{H}, 1.68$ Found C, 24.95; H, 1.65.

Synthesis of 2,5,8-tribromo-1,4-dihydronaphthalene-1,4-diol (11). To a solution of 10 (1.0 g, $2.08 \mathrm{mmol})$ in dry THF $(20 \mathrm{~mL})$ was added a solution of sodium methoxide $(0.28 \mathrm{~g}, 5.0 \mathrm{mmol})$ in dry THF $(15 \mathrm{~mL})$. The mixture was stirred at room temperature for two days during which the progress was checked by TLC. The reaction was diluted with diethyl ether $(20 \mathrm{~mL})$ and washed with $\mathrm{H}_{2} \mathrm{O}(3 \times 20 \mathrm{~mL})$. The organic layer was dried $\left(\mathrm{Na}_{2} \mathrm{SO}_{4}\right)$ and solvent removed under reduced pressure. The residue was purified by column chromatography (dichloromethane-hexane) followed by crystallization from dichloromethane to give $11(0.58 \mathrm{~g}, 70 \%)$. The reaction was repeated using 2 mol equivalents of base $\left(\mathrm{NaOCH}_{3}\right)$ and a similar yield was obtained.

The reaction was repeated using pyridine instead of the both base and solvent. After stirring at room temperature for one day and then extraction, 2,5,8-tribromonaphthalene-1,4-diol 11 was obtained in a yield of $81 \%$.

2,5,8-Tribromo-1,4-dihydronaphthalene-1,4-diol (11): Mp $129-131{ }^{\circ} \mathrm{C} ; R_{f}: 0.55$ (hexane/ethyl acetate; 9:1). ${ }^{1} \mathrm{H}$ NMR (400 MHz, $\left.\mathrm{CDCl}_{3}\right) \delta 7.51$ (s, 2H, H-6 and H-7), 6.62 (d, J3.6 Hz, 1H, H3), 5.41-5.45 (m, 2H, H-1 and H-4), $3.17\left(\mathrm{~d}, J_{1-\mathrm{OH}} 5.6 \mathrm{~Hz}, 1 \mathrm{H}, \mathrm{OH}\right), 3.08\left(1 \mathrm{H}, \mathrm{d}, J_{4-\mathrm{OH}} 6.0 \mathrm{~Hz}\right.$, $1 \mathrm{H}, \mathrm{OH}) ;{ }^{13} \mathrm{C}$ NMR $\left(100 \mathrm{MHz}, \mathrm{CDCl}_{3}\right) \delta 137.2,137.0,134.3,134.2,131.2,125.4,123.5,123.3$, 69.1, 66.7; MS (GC-MS/EI) m/z 396/398/400/402 [1, M] ${ }^{+}, 378 / 380 / 382 / 384\left[9, \mathrm{M}-\mathrm{H}_{2} \mathrm{O}-\mathrm{H}\right]^{+}$, $362 / 364 / 366 / 368\left[11, \mathrm{M}-2 \mathrm{H}_{2} \mathrm{O}\right]^{+}, 317 / 319 / 321$ [53, M-Br] ${ }^{+}, 300 / 302 / 304$ [18, M- $\left.\mathrm{H}_{2} \mathrm{O}-\mathrm{Br}\right]^{+}$, 283/285/287 [5, M-2H $\left.{ }_{2} \mathrm{O}-\mathrm{Br}\right]^{+}, 271 / 273 / 275$ [24], 261/263/265 (7), 238/240 [54, M-2Br] ${ }^{+}$, 220/222 [6, M- $\mathrm{H}_{2} \mathrm{O}-2 \mathrm{Br}$ ], 204/206 [30, M-2 $\mathrm{H}_{2} \mathrm{O}-2 \mathrm{Br}$ ], 191/193/195 (32), 159 [15, M-3Br] ${ }^{+}$, 140/142 [9, M- $\left.\mathrm{H}_{2} \mathrm{O}-3 \mathrm{Br}\right], 131(50), 125$ [33, M-2 $\left.\mathrm{H}_{2} \mathrm{O}-3 \mathrm{Br}\right], 113$ [100, M-3Br-OH] ${ }^{+}, 102$ (63), 86 (50), 74 (91), 62 (65), 56 (46), 51 (47), 38 (16); IR (KBr, cm $\left.{ }^{-1}\right)$ 3313, 2923, 2649, 1671, 1581, 1440, 1390, 1315, 1282, 1257, 1214, 1184, 1165, 1062. Anal. calcd for $\mathrm{C}_{10} \mathrm{H}_{7} \mathrm{Br}_{3} \mathrm{O}_{2}: \mathrm{C}, 30.11 ; \mathrm{H}$, 1.77 Found C, 30.02; H, 1.79.

Synthesis of 2,5,8-tribromonaphthalene-1,4-dione (12). A solution of the diol 11 (0.46 g, 1.10 $\mathrm{mmol}$ ) in dichloromethane $(30 \mathrm{~mL})$ was added to pyridinium chlorochromate (PCC, $200 \mathrm{mg}$, $0.72 \mathrm{mmol})$ in dichloromethane $(20 \mathrm{~mL})$. The mixture was stirred at room temperature for 3 
days. The solid was filtered off and the solvent was removed under reduced pressure. The residue obtained was purified by column chromatography (silica gel; dichloromethane) followed by crystallization from dichloromethane-hexane (2:1 in volume) to give pure $\mathbf{1 2}$ (132 $\mathrm{mg}, 78 \%$ ).

2,5,8-Tribromonaphthalene-1,4-dione (12): Mp 188-190 ${ }^{\circ} \mathrm{C}$. $R_{f}$ : 0.6 (hexane/ethyl acetate; 9:1). ${ }^{1} \mathrm{H}$ NMR (400 MHz, $\left.\mathrm{CDCl}_{3}\right) \delta 7.83$ (bs, 2H, H-6 and H-7), 7.56 (s, 1H, H-3); ${ }^{13} \mathrm{C}$ NMR (100 $\left.\mathrm{MHz}, \mathrm{CDCl}_{3}\right) \delta 179.8,176.1,141.0,140.7,139.9,138.6,131.4,131.0,123.2,122.2$; (GCMS/EI), m/z 344/346/348 (7), 329/331/333 (6), 314/316/318/320 [2, M-Br] $]^{+}, 281$ (1), 260 (12), 245/247/249 (13), 235 [7, M+2Br], 209 (9), 181 (4), 155 [27, M-3Br] ${ }^{+}, 153$ [21, M-3Br-2H] , 119 (3), 99 (9), 87 (41), 74 (100), 69 (83), 53 (24), 44 (7), 41 (12); IR (KBr, cm ${ }^{-1}$ ) 3411, 3068, 2921, 2360, 1679, 1608, 1538, 1427, 1365, 1307, 1253, 1209, 1064. Anal. Calcd for $\mathrm{C}_{10} \mathrm{H}_{3} \mathrm{Br}_{3} \mathrm{O}_{2}$ : C, 30.42; H, 0.77 Found C, 30.50; H, 0.81.

The direct oxidation of 2,3,5,8-tetrabromonaphthalene-1,4-diol (10) with PCC. To a solution of pyridinium chlorochromate (PCC, $370 \mathrm{mg}, 1.71 \mathrm{mmol})$ in methylene chloride $(10 \mathrm{~mL})$ was added a solution of 2,3,5,8-tetrabromo-1,4-dihydronaphthalene-1,4-diol (10) (0.37 g, $0.7 \mathrm{mmol})$ in methylene chloride $(12 \mathrm{~mL})$. The mixture was stirred at ambient temperature for 3 days. Reaction progress was monitored for consumption of the starting material by TLC. The residue was filtered through a short silica gel $(10 \mathrm{~g})$ column, eluting with dichloromethane $(120 \mathrm{~mL})$. After removal of the solvent under vacuum, 2,5,8-tribromoanaphthalene-1,4-dione (12) (280 mg, $86 \%$ ) was obtained.

\section{References}

1. Woo, S. B.; Kim, D. Y. Beilstein J. Org. Chem. 2012, 8, 699.

2. Tandon, V. K.; Yadav, D. B.; Singh, R. V.; Chaturvedi, A. K.; Shukla, P. K. Bioorg. Med. Chem. Lett. 2005, 15, 5324.

3. Bolognesi, M. L.; Lizzi, F.; Perozzo, R.; Brun, R.; Cavalli, A. Bioorg. Med. Chem. Lett. 2008, 18, 2272.

4. Del Corral, J. M. M.; Castro, M. A.; Gordaliza, M.; Marton, M. L.; Gualberto, S. A.; Gamito, A. M.; Vuevas, C.; San Feliciano, A. Bioorg. Med. Chem. 2005, 13, 631.

5. Bakare, O.; Ashendel, C. L.; Peng, H.; Zalkow, L. H.; Burgess, E. M. Bioorg. Med. Chem. 2003, 11, 3165 .

6. Oliveira, C. G. T.; Miranda, F. F.; Ferreira, V. F.; Freitas, C. C.; Rabello, R.; Caballido, J. M.; Correa, L. C. D. J. Braz. Chem. Soc. 2001, 12, 339.

7. Verma, R. P. Anti-Canc. Agents Med. Chem., 2006, 6, 489.

8. Da Silva, F. C.; Ferreira, S. B.; Kaiser, C. R.; Pinto, A. C.; Ferreira, V. F. J. Braz. Chem. Soc. 2009, 20, 1478.

9. (a) Çakmak, O. J. Chem. Res. 1999, 366. (b) Çakmak, O.; Demirtaş, I.; Balaydin, H. T. Tetrahedron 2002, 58, 5603. (c) Erenler, R; Çakmak, O. J. Chem. Res. 2004, 566. (d) Erenler, R., Çakmak, O., J. Chem. Res. 2004, 545. (e) Erenler, R.; Demirtaş, İ.; Büyükkıdan, 
B.; Çakmak, O. J. Chem. Res., 2006, 753. (f) Çakmak, O.; Erenler, R.; Tutar, A.; Çelik, N. J. Org. Chem. 2006, 71, 1795. (g) Berkil Akar, K.; Çakmak, O.; Büyükgüngör, O.; Şahin. E. Beilstein J. Org. Chem., 2011, 7, 1036.

10. Daştan, A.; Tahir, M. N.; Ülkü, D.; Balcı, M. Tetrahedron 1999, 55, 12853. 